БАЛЧУГОВ Аркадий Владимирович - аспирант кафедры теории политики и коммуникации Нижегородского государственного университета им. Н.И. Лобачевского (603950, Россия, г. Нижний Новгород, ул. Ульянова, 2; islam-imomi@yandex.ru)

ПАХОМОВА Елизавета Александровна - кандидат исторических наук, доцент; доцент кафедры философии и социально-правовых наук Волжского государственного университета водного транспорта (603950, Россия, г. Нижний Новгород, ул. Нестерова, 5; pahomova-e@inbox.ru)

УСТИНКИН Сергей Васильевич - доктор исторических наук, профессор; декан факультета международных отношений, экономики и управления Нижегородского государственного лингвистического университета им. Н.А. Добролюбова (603950, Россия, г. Нижний Новгород, ул. Минина, 31А; sv.ustinkin@gmail.com)

ФОМЕНКОВ Артем Александрович - доктор исторических наук, доцент; профессор кафедры истории, регионоведения и журналистики Нижегородского государственного лингвистического университета им. Н.А. Добролюбова (603950, Россия, г. Нижний Новгород, ул. Минина, 31A; artjom2310@inbox.ru)

\title{
ПЕРСПЕКТИВЫ ВЗАИМООТНОШЕНИЙ ТРАДИЦИОННЫХ И НОВЫХ МЕДИА
}

Аннотация. В статье анализируются проблемы взаимоотношений традиционных СМИ и новых медиа. Авторы выявляют особенности взаимодополнения и конкуренции между ними в современных реалиях, делают прогноз относительно перспектив традиционных СМИ, обозначают преимущества (особенно возможность практически любому человеку обратиться к широкой аудитории) и недостатки новых медиа, включая качество контента и стиля подачи материалов. В статье указывается на бо́льшую воспитательную роль традиционных СМИ в сравнении с новыми медиа, а также отмечается более высокий профессиональный уровень журналистов в сравнении с блогерами. Авторы определяют возможности сохранения и эффективного функционирования традиционных медиа в ближайшей перспективе. В статье ситуация с новыми медиа уподобляется ситуации с «токенизированными платежами» в современной Российской Федерации и указывается на возможность увеличения аудитории новых медиа, в т.ч. и политизированных.

Ключевые слова: традиционные медиа, новые медиа, взаимоотношения, перспективы, блогинг, политическая сфера

B настоящее время есть несколько значимых вопросов относительно путей развития журналистики и блогинга в ближайшей перспективе. Отметим при этом, что вопросы, которые будут приведены нами ниже в данной работе, характерны не только для России, а являются интернациональными.

Итак, формулировки вопросов следующие.

1. Какими будут в ближайшей перспективе взаимоотношения между традиционными и новыми медиа?

2. Станут ли традиционные медиа маргинальными под влиянием новых медиа?

3. В чем заключаются основные преимущества новых медиа по сравнению с традиционными, и что следует признать их слабыми сторонами?

4. В чем выражается негативное влияние новых медиа на социум?

Сразу хотелось бы подчеркнуть, что у нас совершенно отсутствует стремление давать ответы по принципу, имевшему место в шедеврах советского киноискусства: имеются в виду идеи, что «народные театры вытеснят академические» и «вокруг будет одно только телевидение».

Скорее мы склоняемся к мнению, что взаимодополнение традиционных и новых медиа будет сохраняться. Процесс этот, начавшийся более 10 лет назад 
с того, что газеты, журналы и другие СМИ создали свои официальные страницы во всемирной паутине, продолжается и по сей день. Часть СМИ, правда, окончательно уходит в виртуальное пространство, однако нельзя не отметить, что такие издания как бы берут с собой все лучшее: прежде всего, профессионализм сотрудников и репутацию - то, что имелось у них в эпоху до широкого распространения Интернета.

Часть традиционных СМИ будут ликвидированы. Главная причина - они не выдержали конкуренции с новыми медиа. Победа последних связана в т.ч. и с такими значимыми характеристиками современных общественных отношений, как интенсивное развитие блогосферы и появление новых акторов социальных отношений, а также с возможностью глобальной коммуникации, не зависящей от географических и языковых границ [Пашинская 2018: 136].

Далее отметим, что мы скорее не согласны с довольно распространенной точкой зрения, что «блогеры и сетевые проекты не заменяют журналистов и СМИ, равно как и журналисты не являются блогерами. Это игроки двух относительно автономных друг от друга пространств. Поэтому уместно говорить скорее не о блоггинге как замене журнализма или новом журнализме, а о блоггинге как внешней практике по отношению к журнализму в условиях, когда аудитория СМИ мигрирует в Интернет и приобретает новые черты и новые модели потребления информации» [Гавра, Декалов 2018: 77]. По нашему мнению, новые медиа, включая блоги, как раз и являются конкурентами (особенно в борьбе за аудиторию, ее свободное время и интерес) традиционных медиа. То есть, взаимодополнение не является единственным форматом отношений между традиционными и новыми медиа.

Далее, с нашей точки зрения, необходимо указать на важную характеристику новых медиа, заключающуюся в следующем. Донести свою точку зрения (а в ряде случаев - просто информацию о себе) может теперь практически любой пользователь Интернета. Исследователи справедливо отмечают, что «благодаря свободе общения пользователь может осуществлять самопрезентацию своей личности и собственного творчества на различных сайтах, при этом, следует заметить, его настоящая, реальная жизнь далеко не всегда отождествляется с виртуальной жизнью» [Ляпун, Хабекирова 2016: 79]. Кроме того, «смещение бытия в сторону виртуального пространства изменило и ценностное содержание статуса. Отныне не капитал символизирует успех, а приобретенное внимание (количество просмотров в сети Интернет» [Шляков 2016: 34].

В результате в современных реалиях с помощью блогов и иных новых медиа создана почва для всевозможного самовыражения [Пацук 2019]. Кроме того, пользователи социальных сетей, обладающие большим социальным капиталом, «оказываются более весомыми, чем некоторые федеральные медиа, и это реальность, с которой приходится считаться» [Шатина, Шатин 2015: 19].

Мы согласны с мнением исследователей, отмечавших, что отличительная черта новых СМИ состоит в том, что их содержание создает аудитория. Как отмечают авторы книги «Эпидемия контента», «люди используют социальные СМИ для выражения своего мнения, творчества, для передачи новостей о своих увлечениях и вообще для “социализации” ... они создают свою аудиторию, масштаб которой может соперничать с размерами аудиторий традиционных СМИ» [Филатова 2010: 283].

В рамках изложенного нами выше уместно выделить как положительные, так и отрицательные стороны данных явлений и процессов. Во многом они представляют собою две стороны медали. Прежде всего это касается возможности самовыражения, ранее немыслимого для большинства с помощью традиционных СМИ. Разумеется, это плюс, ибо немало людей с высоким интеллектом, 
богатым жизненным опытом, отличающихся гражданской позицией, могут теперь донести свою мнение по какому-либо злободневному вопросу до широкой аудитории. Однако, как показала практика, наряду с людьми, отличающимися приведенными нами выше характеристиками, в виртуальном пространстве весьма заметны и индивиды, чья жизненная позиция далека от идеала, а интеллект, чувство такта и т.п. оставляют желать лучшего. При этом же число просмотров и даже лайков в ряде случаев выше именно у таких пользователей сети.

Хорошо ли, что аудитория во многом диктует, что именно она хочет прочитать/посмотреть и т.п.? Разумеется, клиентоориентированный подход не может вызывать отторжение. Однако самарский исследователь К.С. Поздняков справедливо отметил, что «желание обзавестись новыми подписчиками в сети, получить большее количество просмотров приводит к тому, что самые разные онлайн-издания начинают писать об одном и том же, теряется представление о значимости уникального контента, оригинальности авторского высказывания» [Поздняков 2018: 16]. Кроме того, нельзя не признать, что традиционные СМИ во всех странах в той или иной мере стремились не только сформулировать «повестку дня», но также и продвигать ценности среди своей аудитории - в т.ч. и ценности положительные, без всяких скидок на время и территориальный охват. Действительно стояли вопросы: «Что мы должны сказать нашему читателю/слушателю/зрителю?» Воспитательная интонация, высокий публицистический настрой, особая ответственность» [Балмаева, Плотников 2012: 231] - все это было характерно для традиционных СМИ.

В новых же медиа и воспитательная интонация, и даже хороший литературный язык зачастую отсутствуют напрочь. Разумеется, есть блоги, созданные либо профессиональными журналистами, либо же людьми образованными и с хорошим вкусом, наличествуют также и весьма качественные интернет-СМИ, однако нельзя не признать, что качество и контента, и стиля его подачи не являются гарантией успеха новых медиа. Мало того, для многих новых медиа характерны и сниженная лексика, и весьма интеллектуально бедный контент, и даже наличие весьма небесспорных с морально-этической точки зрения постов.

По итогам сказанного выше можно сделать следующие выводы.

По нашему мнению, ситуация с новыми медиа сходна с ситуацией в современной России с электронными безналичными платежами (напомним, что Российская Федерация является одним из признанных лидеров в мире в этой сфере!). Один из экспертов в данной области недавно отметил, что наряду с этим почетным лидерством есть и один малозаметный минус, заключающийся в следующем: «тогда, в нулевые, мы платили своими наличными, которые у нас были! А сегодня мы совершаем “токенизированные платежи” деньгами, одолженными у банков, потому что своих наличных уже не осталось» ${ }^{1}$. То есть, вместе с «водой» - с монополией традиционных СМИ и их владельцев на доступ к распространению информации - чуть было не был выплеснут и «ребенок» - имеется в виду профессионализм журналистов и осознание гражданской ответственности в первую очередь.

В целом же представляется, что традиционные СМИ сохранятся, причем благодаря именно профессионализму своих журналистов и топ-менеджменту, а также ввиду наличия запроса на качественную аналитику со стороны лиц, причастных к принятию значимых решений. В то же время аудитория новых медиа, особенно блогов, будет возрастать за счет представителей подрастающего поколения.

\footnotetext{
1 Голубицкий С. 2019. Безналичная Россия. - Новая газета. 9 окт. С. 9.
} 


\section{Список литературы}

Балмаева С.Д., Плотников Ю. 2012. Российские исследования «новых медиа»: Читатели и зрители разных «Россий», созданных «новой» и «традиционной» журналистикой. - Российский человек в «разломе эnох»: qио vadis? Материалы XV Международной научно-практической конференции. С. 231-232.

Гавра Д.П., Декалов В.В. 2018. Заменят ли блогеры журналистов? Институциональные и неинституциональные игроки на пересечении медиа и сетевого пространств. - Историческая и социально-образовательная мысль. Т. 10. № 3-2. С. 75-82.

Ляпун С.В., Хабекирова 3.С. 2016. Ценностная парадигма виртуальной коммуникации. - Научно-методическое обеспечение преподавания иностранных языков на неязыковых факультетах в свете теории и практики межкультурной коммуникации: межвузовский сборник. С. 77-80.

Пацук А.А. 2019. Самовыражение в современном обществе. - Аллея науки. T. 3. № 5(32). C. 95-98.

Пашинская В.В. 2018. Электронная коммуникация как возможность формирования нового типа общества. - Наука и образование: хозяйство и экономика; предпринимательство; право и управление. № 10(101). С. 134-137.

Поздняков К.С. 2018. Диалог новых медиа и традиционных СМИ (Итоги работы лаборатории прикладной журналистики СГСПУ). - Поволжский педагогический вестник. Т. 6. № 1(18). С. 15-17.

Филатова О.Г. 2010. Блоги и СМИ, гражданская и традиционная журналистика: Соотношение понятий. - Вестник Санкт-Петербургского универсиmета. Сер. 9. Филология. Востоковедение. Журналистика. № 4. С. 281-287.

Шатина Н.В., Шатин И.М. 2015. Политическое пространство российского сегмента социальной сети Фейсбук. - Вестник РГГУ. Сер. Политология. История. Международные отношения. Зарубежное регионоведение. Востоковедение. № 11(154). С. 18-30.

Шляков А.В. 2016. Социальные аспекты номадизма постмодерна. - Теория и практика общественного развития. № 6. С. 34-36.

BALCHUGOV Arkady Vladimirovich, postgraduate student at the Lobachevsky State University of Nizhny Novgorod (2 Ul'yanova St, Nizhny Novgorod, Russia, 603950; islam-imomi@yandex.ru)

PAKHOMOVA Elizaveta Aleksandrovna, Cand.Sci. (Hist.), Associate Professor; Associate Professor of the Chair of Philosophy and Social and Legal Sciences, Volga State University of Water Transport (5 Nesterova St, Nizhny Novgorod, Russia,603950; pahomova-e@inbox.ru)

USTINKIN Sergey Vasil'evich, Dr.Sci. (Hist.), Professor; Dean of the Faculty of International Relations, Economics and Management, Dobroljubov State Linguistics University of Nizhny Novgorod (31A Minina St, Nizhny Novgorod, Russia, 603950; sv.ustinkin@gmail.com)

FOMENKOV Artiom Aleksandrovich, Dr.Sci. (Hist.), Associate Professor; Professor of the Chair of History, Regional Studies and Journalism, Dobroljubov State Linguistics University of Nizhny Novgorod (31A Minina St, Nizhny Novgorod, Russia,603950; artjom2310@inbox.ru)

\section{PROSPECTS FOR RELATIONS BETWEEN TRADITIONAL AND NEW MEDIA}

\footnotetext{
Abstract. The article analyzes the problems of relations between traditional and new media and reveals features of complementarity and competition between them in modern realities. The authors make a forecast concerning prospects of traditional mass media, show the advantages (especially the ability of almost anyone to appeal to a wide audience) and
} 
disadvantages of new media, including the quality of content and style of presentation. The article points out the great educational role of traditional media in comparison with new ones and a higher professional level of journalists compared to bloggers. The authors determine possibilities for the preservation and effective functioning of traditional media in the nearest future. The paper compares the situation with new media to the situation with tokenized payments in the modern Russia. The authors believe there is an opportunity to increase the audience of new media.

Keywords: traditional media, new media, relationships, perspectives, blogging, political sphere

АБРАМОВ Валерий Леонидович - доктор экономических наук, профессор; главный научный сотрудник Центра социально-политических исследований Института развития интеграционных процессов Всероссийской академии внешней торговли (117312, Россия, Москва, ул. Вавилова, 7); главный научный сотрудник Института исследований международных экономических отношений Финансового университета при Правительстве РФ (125993, Россия, г. Москва, ГСП-3, Ленинградский $n p-\kappa m, 49 ;$ valabr@yandex.ru)

ЖИВАЛОВ Владимир Николаевич - доктор экономических наук, член РАЕН; аналитик Центра социально-политических исследований Института развития интеграционных процессов Всероссийской академии внешней торговли (117312, Россия, г. Москва, ул. Вавилова, 7; vzhivalov@ vavt.ru); профессор Российской академии народного хозяйства и государственной службы при Президенте РФ (119571, Россия, г. Москва, пр-кт Вернадского, 82, стр. 1)

ИВАНЧЕНКО Виктория Сергеевна - аналитик Центра социально-политических исследований Института развития интеграционных процессов Всероссийской академии внешней торговли Министерства экономического развития РФ (117312, Россия, г. Москва, ул. Вавилова, 7; viktoriia. ivanchenko@gmail.com)

ПЕРЕХОД Елена Константиновна - аналитик Центра социально-политических исследований Института развития интеграционных процессов Всероссийской академии внешней торговли Министерства экономического развития (117312, Россия, г. Москва, ул. Вавилова, 7; ереrekhod@ vavt.ru)

ЧИМИРИС Екатерина Сергеевна - кандидат политических наук, аналитик 1-й категории Центра социально-политических исследований Института развития интеграционных процессов Всероссийской академии внешней торговли Министерства экономического развития (117312, Россия, г. Москва, ул. Вавилова, 7); доцент департамента политологии факультета социальных наук и массовых коммуникаций Финансового университета при Правительстве РФ (125993, Россия, 2. Москва, ГСП-3, Ленинградский пр-кm, 49; Chimiris@gmail.com)

чИСТИЛИН Дмитрий Константинович - кандидат экономических наук, академик РАЕН; руководитель Центра социально-политических исследований Института развития интеграционных процессов Всероссийской академии внешней торговли (117312, Россия, г. Москва, ул. Вавилова, 7; chistilin@vavt.ru)

\section{ЭКСПЕРТНЫЕ ПОДХОДЫ К ИССЛЕДОВАНИЮ СОЦИАЛЬНЫХ СЕТЕЙ В ИНТЕРНЕТЕ НА ПОСТСОВЕТСКОМ ПРОСТРАНСТВЕ (на примере Молдовы)}

\footnotetext{
Аннотация. Влияние социальных сетей в современном мире сложно переоценить. Они стали полноценным каналом политической коммуникации и формирования общественного мнения. В случае применения специальных методов анализа материалы социальных сетей открывают большие возможности для прогнозирования и формирования коллективного поведения населения. Гипотеза авторов заключается
} 